\title{
Pemodelan Kesesuaian Habitat Katak Serasah (Leptobrachium Hasseltii Tschudi 1838) dengan Sistem Informasi Geografis di Pulau Jawa
}

\section{Modelling the Habitat Suitability of Hasselt's Litter Frog (Leptobrachium hasseltii Tschudi 1838) using Geographic Information System in Java Island}

Anika Putri, Mirza Dikari Kusrini, Lilik Budi Prasetyo

Departemen Konservasi Sumberdaya Hutan dan Ekowisata, Fakultas Kehutanan, Institut Pertanian Bogor, Kampus IPB Darmaga, Bogor 16680, Indonesia

\section{Article Info:}

Received: 24 - 07 - 2019

Accepted: 05 - 09 - 2019

Keywords:

Habitat suitability, hasselt's litter frog, maxent, GIS, modeling.

Corresponding Author:

Anika Putri

Departemen Konservasi Sumberdaya Hutan dan Ekowisata, Fakultas Kehutanan, Institut Pertanian Bogor;

Email: anikaputrip@gmail.com

How to cite (CSE Style $8^{\text {th }}$ Edition):

\begin{abstract}
Hasselt's litter frogs (Leptobrachium hasseltii Tschudi 1838) is a wide spread species in Java and Sumatra, however, the specific distribution map for this species is not available. The purpose of this study is to identify the distribution of hasselt's litter frogs in Java and to examine the suitability map of the species by using maximum entropy method. We used presence data and environment variables consist of elevation, slope, NDVI (Normalized Difference Vegetation Index), distance from the river, temperature, precipitation, and land cover types to develop the distribution model of this species. Hasselt's litter frogs in Java depends on forested area with a wide range of elevation (lowland to mountain forests), moderate slope, temperature between $20-21^{\circ} \mathrm{C}$ and rainfall over $2500 \mathrm{~mm} /$ year. The highest number of frogs are found in secondary forest land cover, NDVI values between 0.8 to 0.9 and relatively close to the river. Habitat model constructed are robust with AUC (Area Under Curve) value of 0.951. Environmental variables that most affectted habitat for hasselt's litter frog are land cover, temperature, and slope.
\end{abstract}

Putri A, Kusrini MD, Prasetyo LB. 2019. Pemodelan kesesuaian habitat Katak Serasah (Leptobrachium Hasseltii Tschudi 1838) dengan sistem informasi geografis di Pulau Jawa. JPSL 10(1): 12-24. http://dx.doi.org/10.29244/jpsl.10.1.12-24.

\section{PENDAHULUAN}

Pemetaan terkait amfibi di Pulau Jawa tergolong masih jarang dilakukan. Penelitian terbaru yang dilakukan Afrianto (2015) mendata sebanyak 38 jenis amfibi yang terbagi ke dalam 7 famili di Pulau Jawa. Data tersebut berdasarkan spesimen amfibi yang terdapat di Laboratorium Herpetologi MZB (Museum Zoologicum Bogoriense) dan dari berbagai literatur penelitian di bidang amfibi. Katak serasah (Leptobrachium hasseltii Tschudi 1838) merupakan salah satu jenis amfibi yang terdapat di Pulau Jawa. Berudu katak serasah tergolong sensitif terhadap kondisi kekurangan mineral lingkungan pada air, berudu akan gagal bermetamorfosis dan tetap menjadi berudu selama hidupnya (Iskandar, 1998). Hal ini dapat menjadikan berudu jenis ini sebagai bio-indikator dari kualitas air.

Katak serasah (Leptobrachum hasseltii Tschudi 1838) merupakan jenis dari famili Megophrydae dan genus Leptobrachium. Ciri khusus dari jenis katak ini yaitu iris berwarna hitam (Hamidi dan Matsui, 2010), ukuran kepala yang lebar, badan ramping, dan kaki tergolong pendek, sehingga pergerakannya tergolong lambat seperti merayap. Katak serasah memiliki penyebaran yang luas di Indonesia yakni Jawa, Sumatra, Madura dan Kangean (IUCN ver 3.1 2016; Iskandar, 1998) dan Borneo (Lathrop et al., 1998). Namun 
penyebarannya secara spesifik di Pulau Jawa belum banyak diketahui. Umumnya data mengenai penemuan katak serasah didapatkan dari hasil inventarisasi keanekaragaman amfibi. Penelitian terkait habitat katak serasah telah dilakukan oleh Sasikirono (2007) menggunakan 6 variabel lingkungan yaitu komposisi vegetasi, penutupan tajuk, suhu, kelembaban udara, ketebalan dan kelembaban serasah. Hasil yang didapatkan lebih bersifat mikrohabitat, sehingga untuk melakukan kajian habitat katak serasah secara luas diperlukan teknologi Sistem Informasi Geografis (SIG) dan pemodelan spasial.

SIG merupakan sebuah alat bantu manajemen berupa informasi berbantuan komputer yang terkait dengan sistem pemetaan dan analisis terhadap segala sesuatu, serta peristiwa-peristiwa yang terjadi di muka bumi (Qoriani, 2012). Penelitian mengenai pemodelan distribusi spesies untuk katak di Jawa telah dilakukan oleh Lubis (2010), namun dengan menggunakan metode PCA (Principal Component Analysis). Metode lain yang dapat digunakan yaitu dengan metode maxent, yaitu suatu program yang digunakan untuk mengestimasi probabilitas distribusi perjumpaan suatu spesies yang ditentukan oleh variabel lingkungan yang ada (Philips $e t$ al., 2006). Penggunaan maxent tergolong masih jarang di Indonesia. Kelebihan maxent yaitu hanya menggunakan data kehadiran dan variabel lingkungan.

Tujuan dari penelitian ini adalah untuk mengidentifikasi sebaran katak serasah di Pulau Jawa dan untuk menelaah kesesuaian habitat katak serasah dengan aplikasi Maximum Entrophy Modelling (Maxent). Hasil dari penelitian ini diharapkan dapat memberikan model penyebaran secara spesifik dari katak serasah di Pulau Jawa, sehingga dapat menjadi pertimbangan perlindungan pada kawasan yang memiliki kesesuaian habitat tinggi bagi jenis ini, baik di dalam kawasan konservasi maupun di luar kawasan konservasi.

\section{METODE}

\section{Lokasi dan Waktu Penelitian}

Penelitian ini dilaksanakan pada bulan Juni-September 2016 di Laboratorium Analisis Lingkungan dan Pemodelan Spasial, Departemen Konservasi Sumberdaya Hutan dan Ekowisata, Fakultas Kehutanan, Institut Pertanian Bogor, dan Laboratorium Herpetologi MZB, Kabupaten Bogor, Provinsi Jawa Barat.

\section{Alat dan Bahan}

Alat yang digunakan pada penelitian ini antara lain software Arc View 10.3, software Modis Reprojection Tool (MRT), microsoft excel, komputer, dan software Maximum Entropy Modelling (Maxent) version 3.3.3k yang tercantum pada Tabel 1. Objek penelitian yaitu data penemuan katak serasah dan berbagai variabel lingkungan Pulau Jawa.

Tabel 1 Alat yang digunakan dalam penelitian.

\begin{tabular}{ll}
\hline \multicolumn{1}{c}{ Alat } & \multicolumn{1}{c}{ Fungsi } \\
\hline Software ArcView 10.3 & Untuk mengolah data spasial \\
Software Modis Reprojection Tool (MRT) & Untuk mengolah data NDVI dari citra Modis \\
Microsoft excel & Untuk mengolah data kehadiran \\
Laptop & Untuk menjalankan software \\
Software Maximum Modelling (Maxent) version & Untuk mengolah data kesesuaian habitat \\
$3.3 .3 \mathrm{k}$ & \\
\hline
\end{tabular}

Jenis data yang digunakan untuk data kehadiran termasuk ke dalam data sekunder, yakni data-data dari penemuan katak serasah berdasarkan penelitian sebelumnya. Data variabel lingkungan yang digunakan merupakan data pihak ketiga yang sudah melalui pengolahan awal. Data variabel lingkungan yang digunakan yaitu ketinggian, kelerengan, jarak dari sungai, suhu, curah hujan, NDVI (Normalized Difference Vegetation Index), dan tutupan lahan. Penggunaan jenis data bertipe sekunder maupun dari pihak ketiga berdasarkan 
pertimbangan dari segi waktu maupun dana. Tabel 2 memaparkan mengenai jenis data, sumber data, metode pengumpulan data, dan tipe data yang digunakan dalam penelitian ini.

Tabel 2 Jenis data, sumber data, metode pengumpulan data, dan tipe data yang dikumpulkan.

\begin{tabular}{|c|c|c|c|c|}
\hline No & Jenis data & Sumber & $\begin{array}{c}\text { Metode } \\
\text { pengumpulan data }\end{array}$ & Tipe data \\
\hline 1 & Data kehadiran satwa & $\begin{array}{l}\text { Kusrini et al. (2006,2007), Afrianto } \\
\text { (2015), Sasikirono (2007), Irvan } \\
\text { (2014), Kurniati et al. (2001), } \\
\text { Kurniati (2002), Kurniati (2005), } \\
\text { Irvan (2014), Riyanto A (2010), } \\
\text { Eprilurahman et al. (2010), dan } \\
\text { spesimen MZB }\end{array}$ & Studi literature & - \\
\hline 2 & Peta dasar & Bakosurtanal.go.id & Pengunduhan & - \\
\hline 3 & $\begin{array}{l}\text { Ketinggian (ASTER } \\
\text { GDEM) }\end{array}$ & Earthexplorer.usgs.gov & Pengunduhan & Continuous \\
\hline 4 & $\begin{array}{l}\text { Kelerengan (ASTER } \\
\text { GDEM) }\end{array}$ & Earthexplorer.usgs.gov & $\begin{array}{l}\text { Pengunduhan, } \\
\text { Studi literature }\end{array}$ & Continuous \\
\hline 5 & Jaringan sungai & Bakosurtanal.go.id & Pengunduhan & Continuous \\
\hline 6 & $\begin{array}{l}\text { Suhu }(30 \text { arc-seconds } \\
=1 \mathrm{~km} \text {, tile } 39)\end{array}$ & http://www.worldclim.org/bioclim & Pengunduhan & Continuous \\
\hline 7 & $\begin{array}{l}\text { Curah hujan (30 arc- } \\
\text { seconds }=1 \mathrm{~km} \text {, tile } 39)\end{array}$ & http://www.worldclim.org/bioclim & Pengunduhan & Continuous \\
\hline 8 & $\begin{array}{l}\text { NDVI (MOD13Q1, } 16 \\
\text { days, } 250 \mathrm{~m} \text { ) }\end{array}$ & Lpdaac.earthexplorer.usgs.gov & Pengunduhan & Continuous \\
\hline 9 & Tutupan lahan & BAPLAN 2014 & Pengunduhan & Categorical \\
\hline
\end{tabular}

\section{Pengolahan Data}

Data titik koordinat penemuan katak serasah dimasukkan ke dalam Ms. Excel kemudian disimpan ke dalam bentuk comma delimited (csv). Variabel lingkungan yang digunakan pada proses maxent harus dalam bentuk format ascii (asc) dan harus memiliki koordinat, ukuran sel, serta extend (batas terluar model) yang sama, sehingga dalam proses penyamaan tersebut dilakukan pada modelbuilder yang terdapat pada ArcView 10.3 yang sebelumnya tiap variabel lingkungan yang digunakan melalui proses pengolahan awal sebagai berikut.

\section{Pengolahan Data Variabel Lingkungan}

Pengolahan data variabel lingkungan secara menyeluruh dilakukan di software Arcview 10.3, kecuali untuk NDVI yang pengolahan awalnya dilakukan di software MRT. Tahap pembuatan peta ketinggian, kelerengan, jarak dari sungai, suhu, curah hujan, dan tutupan lahan terdapat pada Gambar 1. 


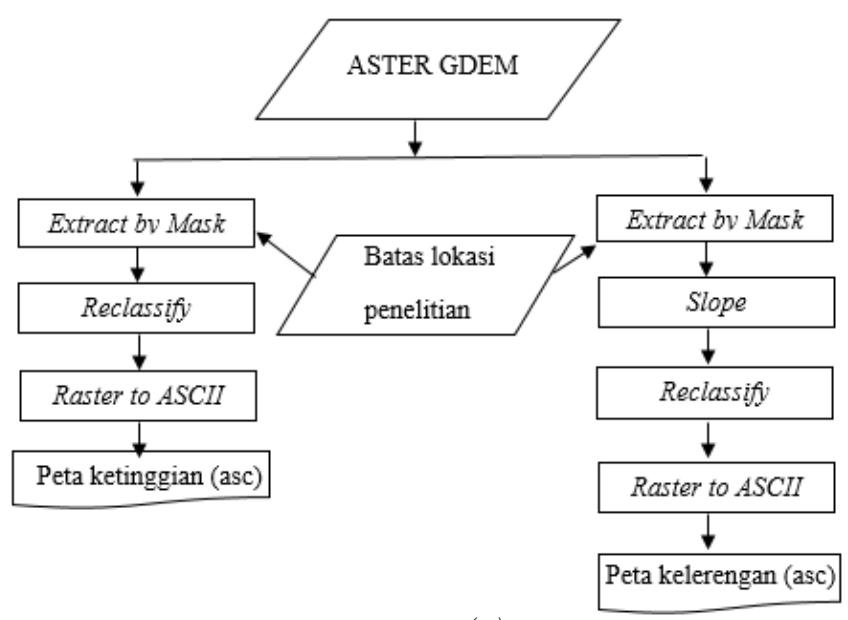

(a)

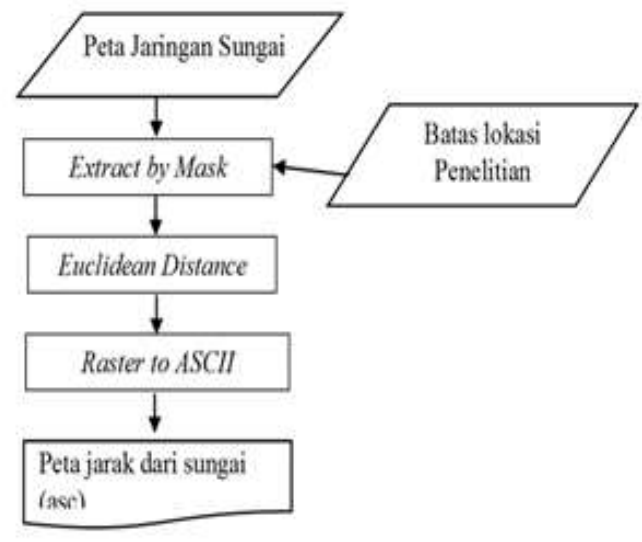

(b)

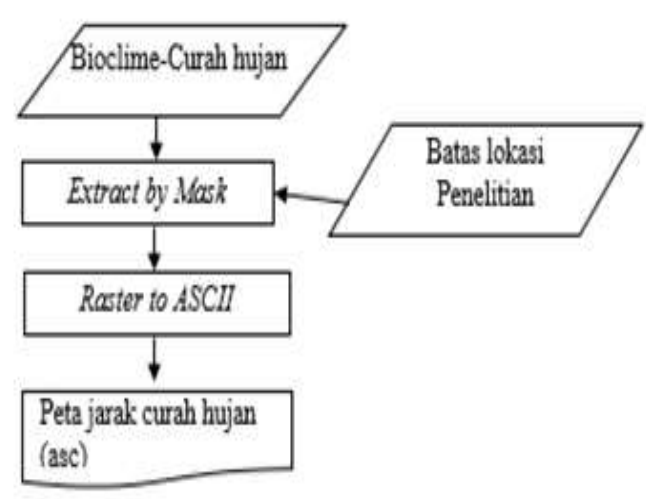

(d)

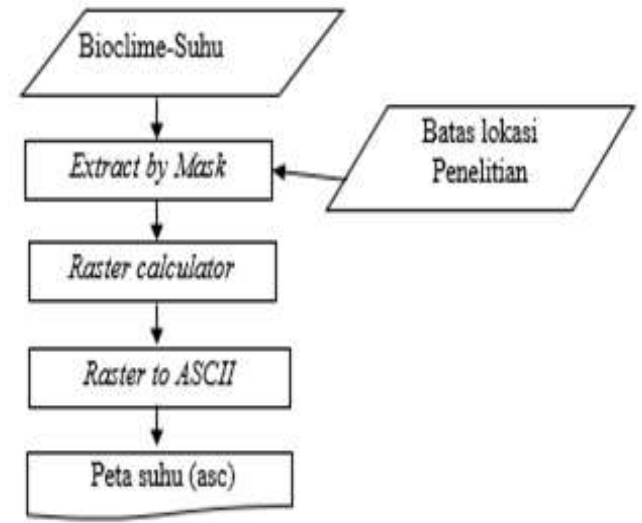

(c)

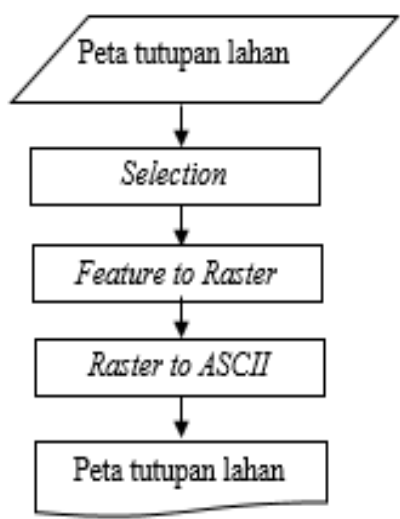

(e)

Gambar 1 Diagram alir pembuatan (a) peta ketinggian dan kelerengan (b) peta jarak dari sungai (c) peta suhu (d) peta curah hujan (e) peta tutupan lahan.

NDVI merupakan suatu nilai indeks vegetasi yang dapat digunakan untuk mengidentifikasi kondisi vegetasi yang ada dan menghitung indeks kanopi tanaman hijau pada data multispectral pengideraan jauh. Data NDVI yang digunakan merupakan data citra modis 16 hari dengan resolusi spasial 250 tipe MOD13Q. Data NDVI didapatkan dengan cara mengesktrak produk MOD13Q dengan menggunakan software MRT, kemudian data tersebut diolah dengan menggunakan software ArcView 10.3. Tahap pembuatan peta NDVI disajikan pada Gambar 2. 


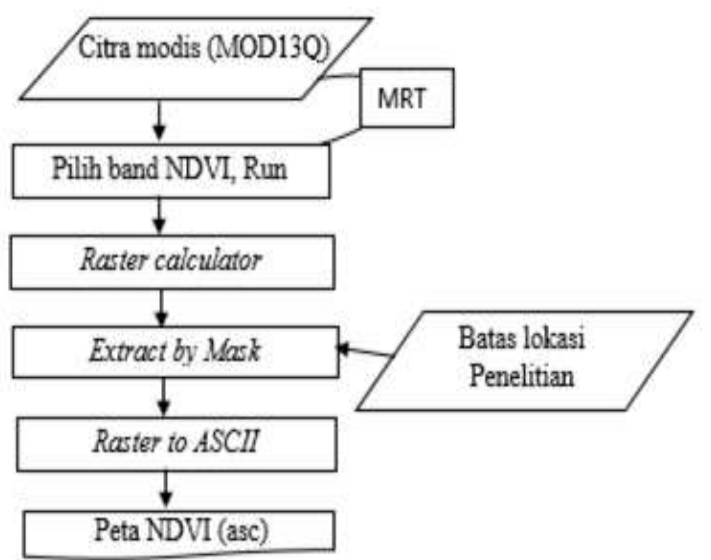

Gambar 2 Diagram alir pembuatan peta NDVI.

\section{Proses Pembuatan Model}

Setiap variabel lingkungan yang sudah melalui proses pengolahan awal, kemudian disamakan koordinat, ukuran sel, dan batas terluarnya. Koordinat yang digunakan yaitu WGS 1984, ukuran selnya yaitu 0.0027, dan batas terluarnya adalah batas Pulau Jawa. Proses penyamaan ini dilakukan di modelbuilder.

\section{Pengolahan Sebaran Katak Serasah}

Proses pengolahan sebaran katak serasah yakni dengan menggunakan data penemuan katak serasah yang sudah ada lalu dihubungkan dengan tipe tutupan lahan, kelerengan, suhu, curah hujan, ketinggian, nilai NDVI, dan jarak dari sungai. Hal ini untuk melihat pengaruh dari variabel lingkungan terhadap penemuan katak serasah.

\section{Pengolahan Maxent}

Proses pengolahan pada software maxent dilakukan dengan memasukkan data titik koordinat berformat csv dan data lingkungan berformat asc. Pengaturan pada menu maxent harus dilakukan pada empat menu yakni utama, basic, advanced, dan experimental. Pengaturan pada menu utama variabel lingkungan dengan menceklis format categorical untuk tutupan lahan dan kelerengan dan format continuous untuk variabel lingkungan yang lain, serta menceklis auto features untuk threshold. Pengaturan pada menu basic semua pilihan diceklis kecuali skip if output exist. Pada random test percentage di isi sebesar $30 \%$, regularization 1 , maximal number of backgroud points 10000, replicates 15 dengan type run subsample. Pengaturan pada menu advanced semua diceklis kecuali append summary results to maxentResult.csv file, mengubah iterations sebesar 5000, dan memilih 10 percentile training presence untuk threshold type, lalu pengaturan lain bersifat default. Pengaturam pada menu experimental dengan menceklis logscale raw/cumulative pictures, write backgroud predictions, show exponent in response curves dan fade by clamping, serta membiarkan pengaturan lain bersifat default.

\section{Analisis Data}

\section{Analisis Tumpang Susun (Overlay)}

Analisis ini dilakukan untuk mengetahui tumpang tindih dari titik penemuan katak serasah dengan variabel lingkungan yang digunakan. Kemudian dilakukan pengkelasan tiap nilai variabel lingkungan yang bertumpang tindih dengan titik koordinat penemuan katak serasah. 


\section{Analisis Multikolinearitas}

Analisis multikolinearitas dilakukan untuk mengetahui hubungan korelasi antar variabel lingkungan yang digunakan, apabila timbul multikolinearitas maka akan mempengaruhi hasil dari pemodelan yang dibuat dan bersifat negatif (Pearson et al., 2007). Pengaruh negatif dari keberadaan mulitikolinearitas ini akan membuat pemodelan yang dihasilkan menjadi overconfident dikarenakan pengaruh dua atau lebih variabel yang saling berhubungan. Nilai ambang batas yang menunjukkan suatu kumpulan variabel memiliki multikolinearitas atau tidak yaitu apabila nilai dari pengolahan yang dihasilkan kurang dari atau sama dengan - 0.75 maupun melebihi 0.75, maka salah satu variabel lingkungan tersebut harus dihilangkan. Metode analisis multikolinearitas yang dilakukan yakni dengan menggunakan Band Collection statistic yang terdapat pada ArcView 10.3.

\section{Validasi Model}

Validasi model yakni dengan melihat nilai Area Under Curve (AUC) test yang didapatkan berdasarkan pengolahan maxent yang dilakukan. AUC merupakan daerah dibawah Receiver Operating Curve (ROC) dan merupakan metode standar untuk mengidentifikasi akurasi prediksi model distribusi (Lobo et al., 2008).

Aturan penggunaan nilai AUC test yang didapatkan yaitu bila nilai di bawah 0.5 maka model tidak bisa diterima, nilai antara 0.5 sampai 0.7 menunjukkan nilai akurasi yang rendah, nilai antara 0.7 sampai 0.9 menunjukkan bahwa model dapat digunakan dengan nilai akurasi yang tergolong sedang, dan bila melebihi 0.9 maka model memiliki nilai akurasi yang tergolong tinggi (Swets, 1988).

\section{Rentang Kelas Kesesuaian Katak Serasah}

Peta kesesuaian habitat katat serasah terbagi menjadi tiga kelas yaitu kelas kesesuaian rendah, kelas kesesuaian sedang, dan kelas kesesuaian tinggi. Rumus yang digunakan dalam penentuan selang pembagian kelas berdasarkan Supranto (2000) yaitu nilai peluang tertinggi dikurangi nilai peluang terendah dan kemudian dibagi banyaknya kelas kesesuaian seperti dijabarkan persamaan berikut.

$$
\mathrm{C}=\frac{X n-X 1}{K}
$$

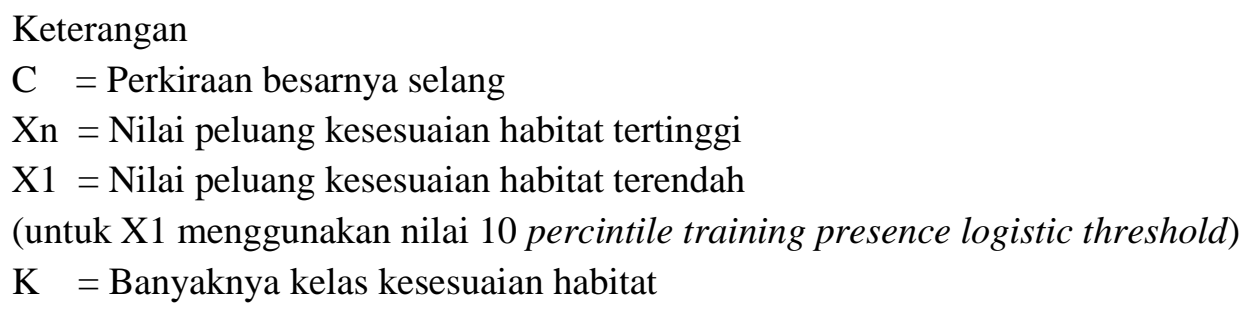

\section{Analisis Deskriptif}

Analisis deskriptif digunakan untuk menganalisis hasil dari aplikasi maxent yang terdiri dari distribusi penyebaran spesies, data terkait faktor lingkungan yang paling berpengaruh, dan data terkait kemungkinan perjumpaan dengan spesies ini di lokasi penelitian. Analisis ini digunakan karena pada program ini, hasil langsung didapatkan oleh pengguna atau user sehingga hal penting yang harus dilakukan adalah interpretasi dari hasil yang disajikan dari software ini. 


\section{HASIL DAN PEMBAHASAN}

\section{Identifikasi Sebaran Katak Serasah di Pulau Jawa}

Hutan sekunder merupakan jenis tutupan lahan dengan titik jumlah penemuan terbesar yakni sebesar 57,14\% dari 77 titik penemuan katak serasah yang digunakan, bila dibandingkan dengan 18 tipe tutupan lahan lain yang terdapat di Pulau Jawa. Kondisi yang mendukung banyaknya jumlah penemuan ini dapat dihubungkan dengan nilai NDVI di lokasi titik katak serasah yang berkisar antara 0.8-0.99. Nilai NDVI menggambarkan mengenai tutupan kanopi tajuk suatu wilayah, apabila mendekati angka 1 menandakan bahwa wilayah tersebut memiliki kanopi tajuk yang rapat dan hijau. Hal ini sesuai dengan pernyataan Iskandar (1998) yaitu bahwa katak serasah hidup di daerah berhutan di tengah-tengah serasah hutan.

Jumlah titik penemuan katak serasah cenderung merata pada ketinggian antara 1000 sampai 2000 mdpl yang merupakan hutan pegunungan, namun terjadi ketidakmerataan pada ketinggian di bawah 1000 mdpl yang merupakan hutan dataran rendah. Faktor-faktor yang dapat memengaruhi hal ini yaitu faktor pencarian yang lebih banyak dilakukan di daerah hutan pegunungan dan inventarisasi satwa yang bersifat umum untuk semua herpetofauna dan tidak difokuskan hanya pada katak serasah. Gambar 3 menunjukan hubungan ketinggian dengan jumlah titik penemuan katak serasah.

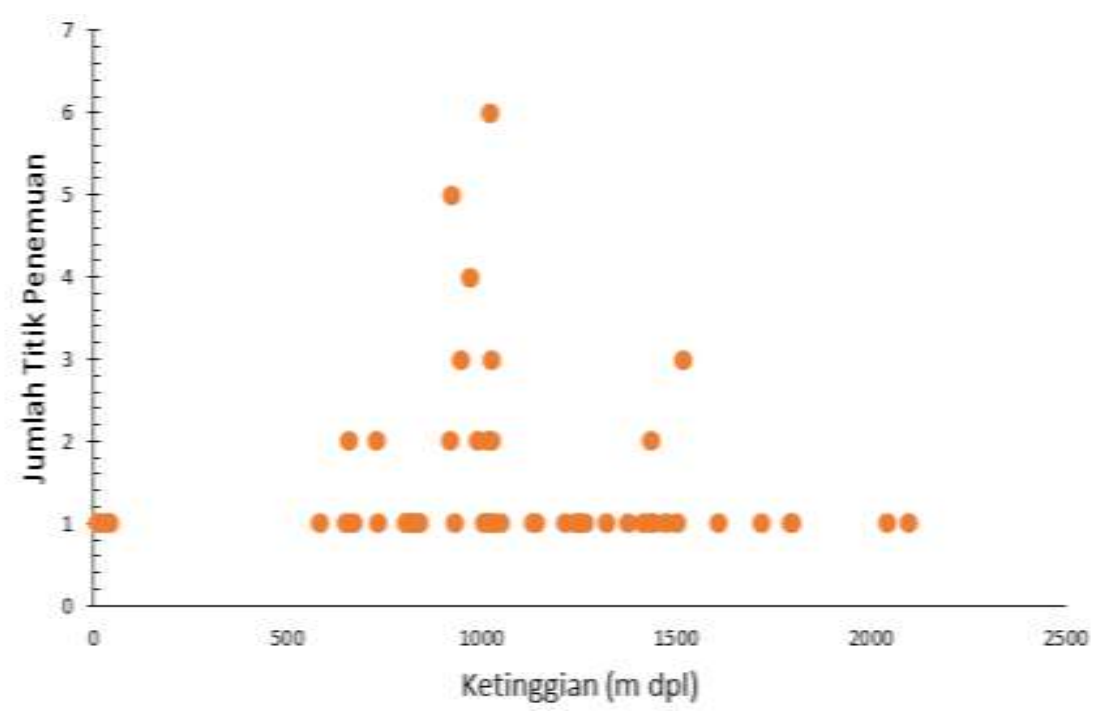

Gambar 3 Hubungan ketinggian dengan jumlah titik penemuan katak serasah.

Kelerangan akan memengaruhi variasi genetik pada amfibi yang diakibatkan lereng yang curam akan menghalangi pergerakan amfibi (Zawacki, 2009). Hal ini menjadi perhatian khusus dikarenakan selain banyak ditemukan di daerah landai (tipe kelas lereng 2) sebesar 27.27\%, amfibi juga banyak ditemukan pada daerah curam (tipe kelas lereng 4) sebesar $24.68 \%$.

Katak serasah ditemukan pada rentang suhu antara 14.5 sampai $27^{\circ} \mathrm{C}$ dengan jumlah titik penemuan yang tergolong bervariasi. Faktor yang dapat memengaruhi antara lain periode pencarian, lokasi, dan kondisi cuaca. Suhu akan memengaruhi aktivitas dan fitur suara katak (Prohl, 2007) yang akan memengaruhi pembiakan dari amfibi (Carey dan Alexander, 2003). Hal ini menjadikan suhu merupakan variabel lingkungan yang penting bagi katak.

Variabel lingkungan lain yang tergolong penting bagi amfibi adalah keberadaan air. Hal ini didukung oleh pernyataan Ryan et al. (2015) bahwa amfibi memiliki hubungan negatif dengan kekeringan dan Walls et al. (2013) yang menghubungkannya dengan kemampuan bertahan hidup, reproduksi, dan pergerakan anakan dewasa amfibi. Berdasarkan hal ini, hasil yang didapatkan menunjukkan bahwa amfibi tergolong menyebar 
merata pada rentang curah hujan antara 2400 sampai $3000 \mathrm{~mm} /$ tahun dan kecenderungan peningkatan jumlah titik penemuan pada curah hujan $2500 \mathrm{~mm} /$ tahun yang disajikan pada Gambar 4.

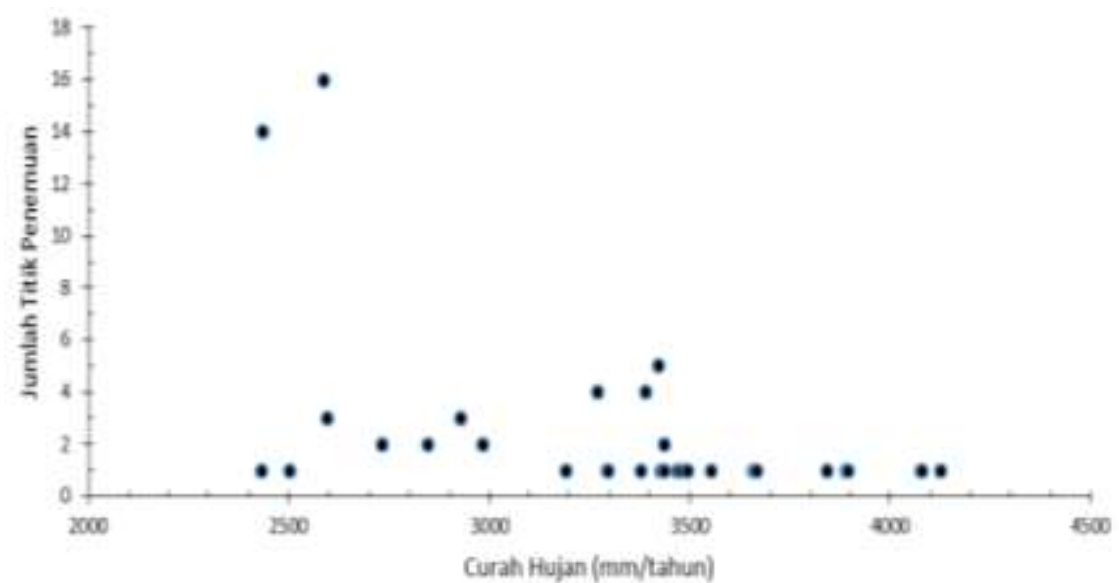

Gambar 4 Hubungan rentang hujan dengan jumlah titik penemuan katak serasah.

Katak serasah merupakan jenis yang berasosiasi dengan keberadaan sungai (Iskandar 1998). Hasil yang didapatkan yaitu titik penemuan katak serasah tergolong dekat dengan badan air. Hal ini didukung dengan hasil penelitian Sasikirono (2007) yang menunjukan bahwa anakan serasah tergolong menyebar dekat dengan sungai, katak jantan tergolong menyebar merata, dan katak betina cenderung jauh dari sungai tapi masih dapat ditemukan pada jarak kurang dari $100 \mathrm{~m}$ dari pinggir sungai.

\section{Besaran Nilai Pengaruh Antar Variabel Lingkungan}

Data antar variabel lingkungan yang telah dianalisis dengan menggunakan Band Collection Statistic menunjukkan bahwa terdapat hubungan korelasi ganda antara layer 1 (ketinggian) dengan layer 5 (suhu). Besaran nilai multikolinearitas yang dihasilkan yaitu sebesar -0.97835. Nilai tersebut menunjukkan bahwa terdapat hubungan negatif antara ketinggian dengan suhu dan juga sebaliknya. Makna nilai negatif tersebut yaitu apabila nilai ketinggian semakin besar maka nilai suhu akan semakin mengecil. Keberadaan kedua variabel tersebut dalam suatu pemodelan akan membuat pemodelan yang dihasilkan menjadi overconfident, sehingga salah satu dari data variabel tersebut harus dihilangkan. Pengujian untuk membandingkan hasil yang lebih baik antar kedua variabel tersebut dengan menghilangkan salah satu variabel dalam pemodelan, hasil yang didapatkan menunjukkan bahwa layer 5 memberikan hasil yang lebih baik dibandingkan dengan layer 1, sehingga hasil pemodelan yang digunakan yaitu yang menggunakan data variabel layer 5 (suhu). Besaran nilai pengaruh antar variabel lingkungan tersebut tersaji pada tabel 3.

Tabel 3 Hasil analisis multikolinearitas

\begin{tabular}{llllllll}
\hline Layer & $1^{*}$ & $2^{*}$ & $3^{*}$ & $4^{*}$ & $5^{*}$ & $6^{*}$ & $7^{*}$ \\
\hline $1^{*}$ & 1.00000 & 0.18007 & 0.39937 & 0.59466 & -0.97835 & -0.00214 & -0.25850 \\
$2^{*}$ & 0.18007 & 1.00000 & 0.25817 & 0.28829 & -0.18938 & 0.00359 & -0.07350 \\
$3^{*}$ & 0.39937 & 0.25817 & 1.00000 & 0.40442 & -0.37054 & -0.00802 & -0.09640 \\
$4^{*}$ & 0.59466 & 0.28829 & 0.40442 & 1.00000 & -0.58266 & -0.00126 & -0.25516 \\
$5^{*}$ & -0.97835 & -0.18938 & -0.37054 & -0.58266 & 1.00000 & 0.00096 & 0.27443 \\
$6^{*}$ & -0.00214 & 0.00359 & -0.00802 & -0.00126 & 0.00096 & 1.00000 & 0.27443 \\
$7^{*}$ & -0.25850 & -0.07350 & -0.09640 & -0.25516 & 0.27443 & -0.00475 & 1.00000 \\
\hline
\end{tabular}

*Keterangan : layer 1=ketinggian; 2=NDVI; 3=curah hujan; 4=kelerengan; 5=suhu; 6=jarak dari sungai; 7=tutupan lahan 


\section{Kesesuaian Habitat Katak Serasah dengan Aplikasi Maxent}

Pengaruh variabel lingkungan pada pemodelan kesesuaian habitat katak serasah ditunjukan berdasarkan hasil dari operasi jacknife. Metode ini merupakan suatu cara untuk menduga kepentingan atau kontribusi tiap variabel lingkungan yang digunakan pada pemodelan (Negga 2007). Hasil dari operasi ini menunjukkan bahwa tutupan lahan, suhu, dan kelerengan memberikan pengaruh terbesar pada pemodelan yang terdapat pada Gambar 5 dan Gambar 6. Penilaian yang dilihat pada operasi jacknife yaitu besaran nilai AUC test dan nilai test gain yang didapatkan akibat dari perlakuan variabel lingkungan yang telah ditentukan. Elith et al. (2011) menyatakan test gain adalah satuan statistik yang menduga seberapa baik prediksi distribusi sesuai dengan data kehadiran yang dibandingkan dengan distribusi seragam. Semakin besar nilai AUC test dan test gain yang didapatkan dari penggunaan variabel lingkungan tertentu, maka variabel lingkungan tersebut tergolong memengaruhi pemodelan yang dibuat. Kriteria lain untuk menentukan seberapa besar pengaruh suatu variabel lingkungan yaitu dengan melihat besaran nilai test gain maupun AUC yang turun ataupun berkurang ketika tidak digunakan dalam pemodelan. Lalu kriteria lainnya untuk variabel lingkungan yaitu apabila memberikan kontribusi tertinggi pada nilai test gain dan AUC ketika hanya menggunakan variabel tersebut, lalu besaran nilai tersebut dibandingkan dengan nilai AUC test dan test gain ketika menggunakan semua variabel. Apabila besaran test gain maupun AUC tidak berbeda jauh maka variabel tersebut merupakan variabel yang memberikan kontribusi tertinggi pada pemodelan tersebut.

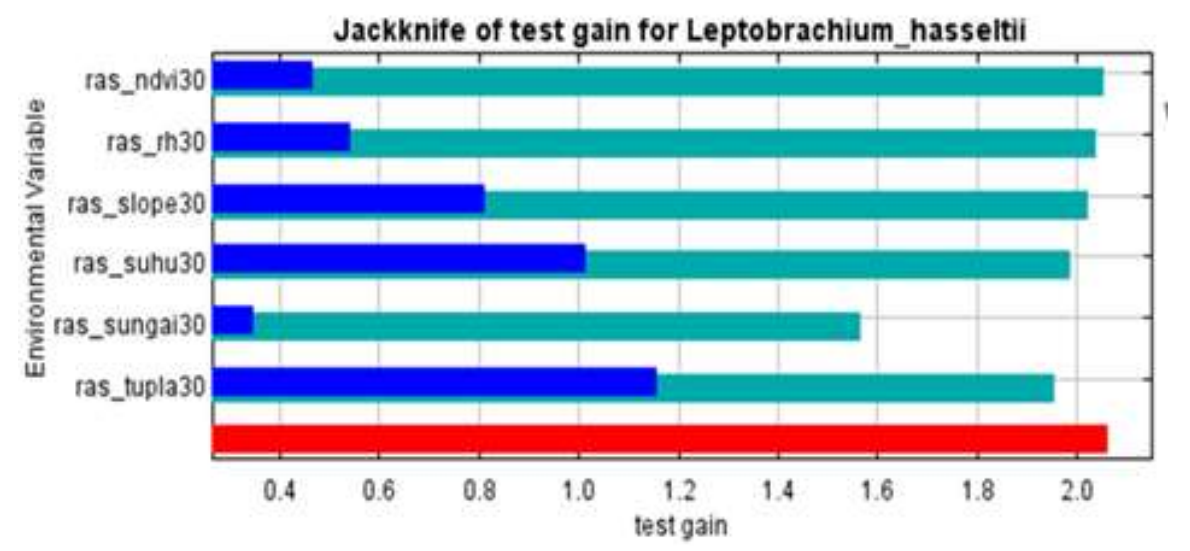

Gambar 5 Pengaruh variabel lingkungan terhadap nilai test gain yang didapatkan.

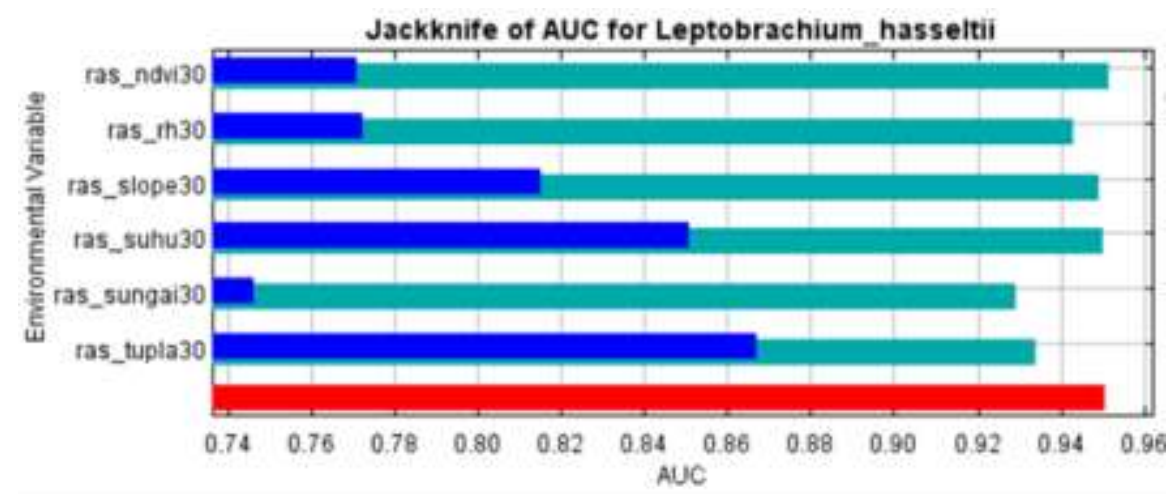

Gambar 6 Pengaruh variabel lingkungan terhadap nilai AUC test yang didapatkan.

(Keterangan : ras_ndvi30=NDVI, ras_rh30=curah hujan, ras-slope30=kelerengan, ras_suhu30=suhu, ras_sungai30=jarak dari sungai, ras_tupla30=tutupan lahan)

(Keterangan : warna biru muda hanya menggunakan salah satu variabel lingkungan; warna biru tua tidak menggunakan salah satu variabel lingkungan; warna merah menggunakan seluruh variabel lingkungan) 
Tutupan lahan memberikan pengaruh terbesar bagi pemodelan terlihat dari nilai AUC dan test gain yang didapatkan. Becker et al. (2007) menyatakan bahwa perubahan tutupan lahan merupakan salah satu faktor terpenting pada penurunan jumlah amfibi secara global. Hal ini menunjukkan bahwa amfibi merupakan satwa yang sangat peka terhadap perubahan tutupan lahan. Selain itu, tutupan lahan menjadi faktor pemilihan habitat bagi suatu satwa untuk memenuhi keperluan hidupnya yakni pakan, cover, shelter, dan air.

Variabel lingkungan lainnya yaitu suhu dan kelerengan. Variabel suhu berkaitan erat dengan pembiakan, sedangkan variabel kelerengan akan memengaruhi peluang perjumpaan antar katak serasah di alam. Perbedaan suhu yang terdapat di pegunungan dan dataran rendah akan membuat perbedaan batas toleransi kenaikan suhu pada tiap individu katak serasah yang akan memengaruhi kemampuan bertahan hidupnya. Selain itu, secara morfologis katak serasah tergolong memiliki kaki yang pendek sehingga pergerakannya lambat dan kelerengan yang tergolong ekstrim akan menjadi pembatas pergerakan katak serasah.

Nilai AUC test adalah nilai yang didapatkan pada pengujian 30\% sampel yang diambil secara acak. Nilai pemodelan yang didapatkan tergolong tinggi yakni 0.951 yang didapatkan dengan menjumlahkan tiap kotak persegi yang terletak di bawah garis merah. Nilai yang didapatkan tersebut menunjukkan bahwa pemodelan yang dibuat dapat digunakan dan memiliki akurasi yang tinggi. Pemilihan metode AUC dalam proses validasi karena metode ini merupakan metode standar untuk menguji validitas suatu pemodelan, selain itu AUC juga memberikan keuntungan bagi pengguna yakni menghindari subjektivitas pada proses pemilihan batas (Lobo et al., 2008). Gambar 7 merupakan ilustrasi dari nilai AUC test yang didapatkan pada pemodelan.

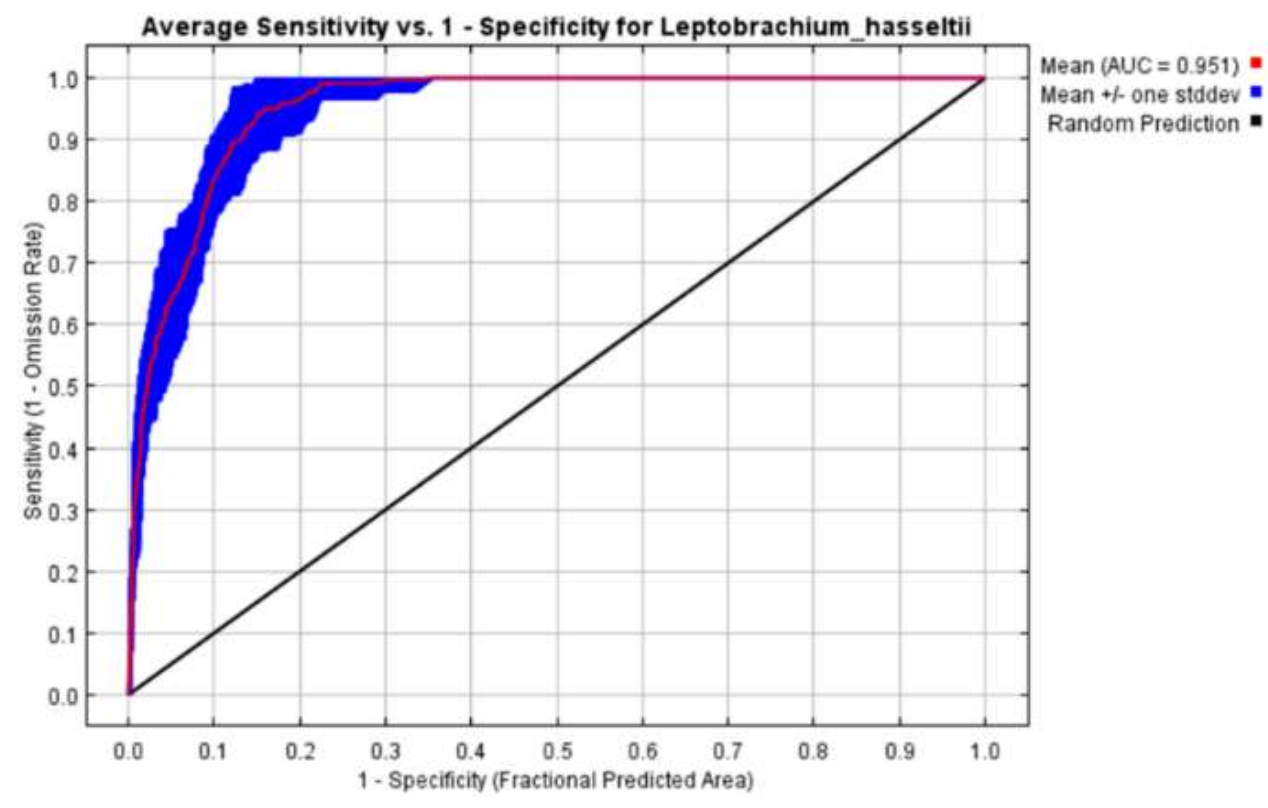

Gambar 7 Ilustrasi nilai AUC test yang didapatkan pada pemodelan.

Kelas kesesuaian habitat katak serasah terbagi menjadi 4 kelas yaitu tidak sesuai, kesesuaian rendah, kesesuaian sedang, dan kesesuaian tinggi. Rentang nilai yang didapatkan antara 0 sampai 0.9664 , lalu dengan pemilihan penggunaan 10 percentile training presence logistic threshold maka daerah yang dianggap sesuai harus memiliki nilai lebih dari 0.2036 . Penggunaan 10 percentile training presence threshold lebih memberikan hasil yang signifikan secara ekologi bila dibandingkan dengan penggunaan threshold lain yang tergolong lebih kaku (Redon dan Luque, 2010). Tabel 4 disajikan rentang tiap kelas kesesuaian habitat katak serasah. 
Tabel 4 Kelas kesesuaian habitat katak serasah di Pulau Jawa.

\begin{tabular}{llll}
\hline No & Kelas kesesuaian & Selang kelas kesesuaian & Persentase $(\%)$ \\
\hline 1 & Tidak sesuai & $0.0000-0.2036$ & 92.37 \\
\hline 2 & Kesesuaian rendah & $0.2036-0.4579$ & 5.44 \\
\hline 3 & Kesesuaian sedang & $0.4579-0.7121$ & 1.74 \\
\hline 4 & Kesesuaian tinggi & $0.7121-0.9664$ & 0.45 \\
\hline
\end{tabular}

Nilai yang lebih besar dari nilai 10 percentile training presence logistic threshold kemudian dibuat menjadi 3 kelas dengan menggunakan ketentuan persamaan dari Supranto (2000) yang telah mengalami modifikasi. Hasil yang didapatkan menunjukkan bahwa luasan wilayah yang tergolong memiliki kesesuaian tinggi tergolong paling sedikit bila dibandingkan dengan kelas kesesuaian yang lain. Lalu habitat tersebut menyebar dari dataran rendah dan juga pegunungan yang tergolong memiliki tutupan hutan yang tergolong rapat. Hal ini diketahui dengan melakukan tumpang susun (overlay) dengan basemap world imagery di Arcview. Ilustrasi kesesuaian habitat katak serasah disajikan pada Gambar 8.

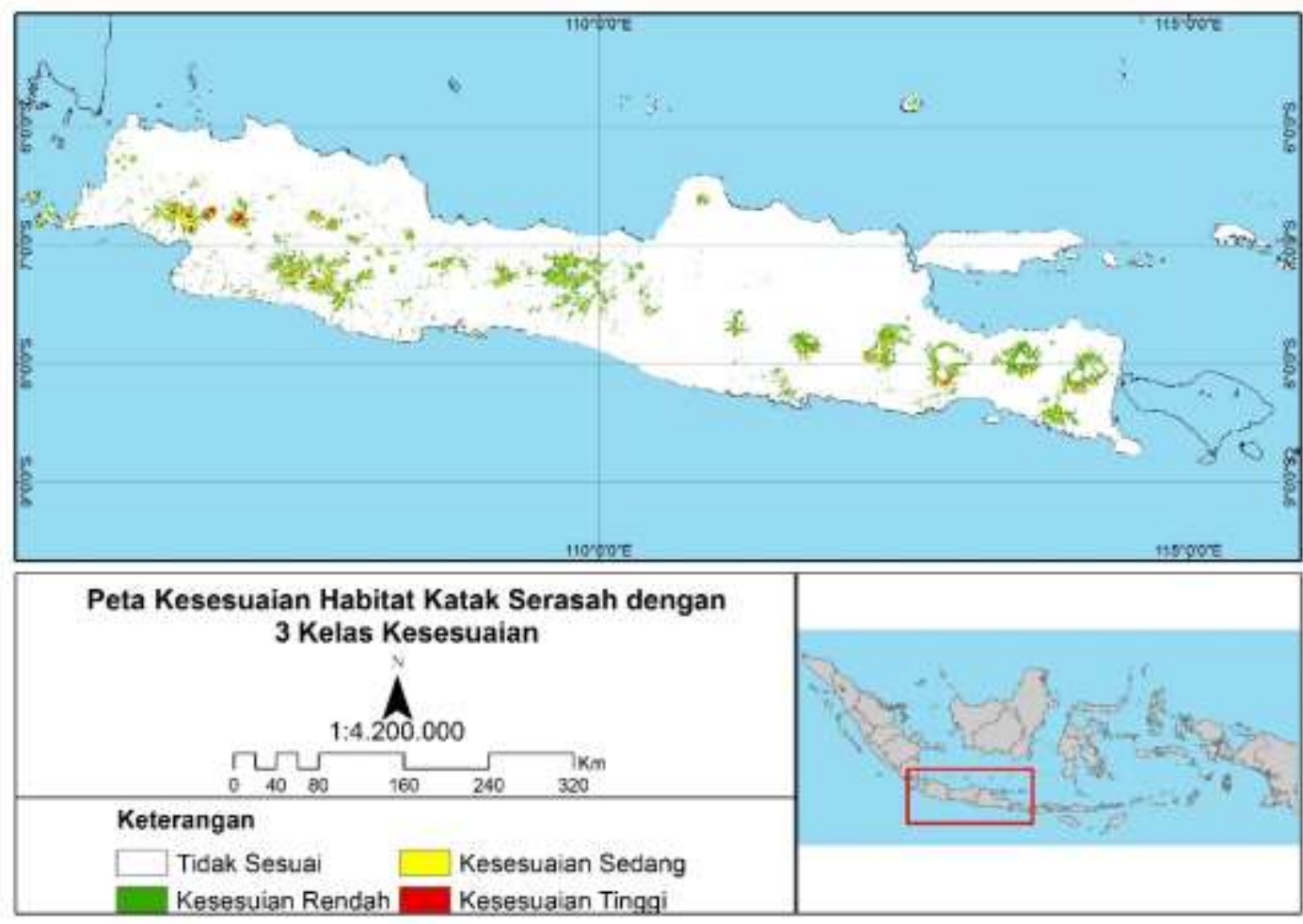

Gambar 8 Peta kesesuaian habitat katak serasah dengan 4 kelas kesesuaian.

\section{SIMPULAN}

Katak serasah di Pulau Jawa tersebar dari hutan dataran rendah sampai hutan pegunungan dengan tutupan vegetasi hijau dan dekat dengan sungai. Sebaran tertinggi ditemukan di wilayah dengan ciri-ciri hutan sekunder, tingkat kelerengan landai, rentang suhu $20-21^{\circ} \mathrm{C}$, dan curah hujan $>2500 \mathrm{~mm} /$ tahun. Pemodelan yang dibuat dapat diterima dengan $\mathrm{AUC}=0.951$. Kontribusi variabel lingkungan tertinggi yakni tutupan lahan, suhu, dan kelerengan. 


\section{UCAPAN TERIMA KASIH}

Ucapan terima kasih penulis sampaikan kepada Dr Ir Mirza Dikari Kusrini, MSi dan Prof Dr Ir Lilik Budi Prasetyo MSc yang telah memberikan arahan dan saran dalam pengerjaan karya ilmiah ini, serta kepada Muhammad Irfansyah Lubis, Shut, MDev Prac, dan Dr Yudi Setiawan atas segala bantuan yang telah diberikan. Ucapan terimakasih juga penulis sampaikan kepada pihak Museum Zoologicum Bogoriense yang telah mengizinkan penulisan untuk menggunakan data spesimen katak serasah.

\section{DAFTAR PUSTAKA}

Afrianto A. 2015. Pemetaan penyebaran amfibi di Pulau Jawa menggunakan aplikasi sistem informasi geografis (SIG). Skripsi. Bogor: Departemen Konservasi Sumberdaya Hutan dan Ekowisata, Fakultas Kehutanan, Institut Pertanian Bogor.

Becker CG, Fonseca CR, Haddad CFR., Batista RF, Prado PI. 2007. Habitat split and the global decline of amphibians. Science. 318: 1775-1776.

Carey C, Alexander MA. 2003. Climate change and amphibian declines: is there a link. Diversity and Distribution. 9: 111-121.

Elith J, Phillips SJ, Hastie T, Dudík M., Chee YE, Yates CJ. 2011. A statistical explanation of MaxEnt for ecologists. Diversity and Distributions. 17: 43-57.

Eprilurahman R., Qurniawan TF, Kusuma KI, Chomsun HK. 2010. Studi awal keanekaragaman herpetofauna di Petungkriyono, Kabupaten Pekalongan, Provinsi Jawa Tengah. Zoo Indonesia. 19: 19-30.

Hamidi A., Matsui M. 2010. A new species of blue-eyed Leptobrachium (Anura: Megophryidae) from Sumatra, Indonesia. Zootaxa. 2395: 34-44.

Irvan. 2014. Perbandingan keanekaragaman dan sebaran spasial amfibi di Pulau Peucang dan Cidaon Taman Nasional Ujung Kulon. Skripsi. Bogor: Departemen Konservasi Sumberdaya Hutan dan Ekowisata, Fakultas Kehutanan, Institut Pertanian Bogor.

Iskandar DT. 1998. Amfibi Jawad dan Bali-Seri Panduan Lapangan. Bogor: Puslitbang-LIPI.

[IUCN] International Union for Conservation of Nature and Natural Resource. 2016. Amphibians on the IUCN Red List [terhubung berkala]. http://www.iucnredlist.org/initiatives/amphibians [2 Agustus 2016].

Kurniati H, Crampton W, Goodwin A, Lockett, Sinkiss S. 2001. Herpetofauna diversity of Ujung Kulon National Park an inventory result in 1990. Berkala Penelitian Hayati. 6: 113-128.

Kurniati H. 2002. Frogs and toads of Ujung Kulon, Gunung Halimun, and Gede Pangrango National Park. Berita Biologi. 6(1): 75-84.

Kurniati H. 2005. Species richness and habitat preferences of herpetofauna in Gunung Halimun National Park West Java. Berita Biologi. 7(5): 263-271.

Kusrini MD, Fitri A. 2006. Final report ecology and conservation of frogs of mount salak, West Java, Indonesia. Bogor: Tidak dipublikasikan.

Kusrini, MD (Ed). 2007. Frogs of Gede Pangrango: a follow up project for the Conservation of Frogs in West Java Indonesia. Book 1: Main Report. Bogor: Technical report submitted to the BP Conservation Programme.

Lathrop A, Murphy RW, Orlov NL, Ho CT. 1998. Two new species of Leptobrachium (Anura: Megophrydae) from the central highlands of vietnam with a redescription of Leptobrachium chapaense. Russian Journal of Herpetology. 1(5): 51-60.

Lobo JM, Valverde AJ, Real R. 2008. AUC: a misleading measure of the performance of predictive distribution models. Global Ecology and Biogeography. 17: 145-151.

Lubis MI. 2008. Pemodelan Spasial Habitat Katak Pohon Jawa (Rhacophorus javanus Boettger 1893) dengan menggunakan Sistem Informasi Geografis Dan Penginderaan Jarak Jauh di Taman Nasional Gunung Gede Pangrango Jawa Barat. Skripsi. Bogor: Departemen Konservasi Sumberdaya Hutan dan Ekowisata, Fakultas Kehutanan, Institut Pertanian Bogor.

Negga HE. 2007. Predictive modelling of amphibian distribution using ecological survey data: a case study of Central Portugal. Tesis. Enschede: International Institute for Geo-Information Science and Earth Observation. 
Pearson RG, Raxworthy CJ, Nakamura M, Peterson AT. 2007. Predicting species distributions from small numbers of occurence records: a test case using cryptic geckos in Madagascar. Journal of Biogeography. 34: 102-117.

Prohl H, Hagemann S, Karsch J, Hobelt G. 2007. Geographic variation in male sexual signals in strawberry poison frogs (Dendrobates pumilio). Ethology. 113: 825-837.

Redon M., Luque S. 2010. Presence-only modelling for indicator species distribution: biodivesity monitoring in the French Alps. 6th Spatial Analysis and Geomatics International Conference (SAGEO 2010). November 2010, Toulouse, France. Universite de Toulouse 1, pp. 42-45.

Riyanto A. 2010. Herpetofauna community structure and habitat associations in Gunung Ciremai National Park, West Java, Indonesia. Biodiversitas. 12: 38-44.

Ryan, MJ, Scott, NJ, Cook JA, Willink B, Chaves G, Bolanos F, Rodriguez AG, Latella I.M, Koerner SK. 2015. Too wet for frogs: changes in a tropical leaf litter community coincede with la nina. Ecosphere. 6: $1-10$.

Sasikirono. 2007. Studi karakteristik habitat sekitar sungai dan danau serta biologi katak serasah Leptobrachium hasseltii Tschudi, 1838 di Situ Gunung Sukabumi. Skripsi. Bogor: Departemen Konservasi Sumberdaya Hutan dan Ekowisata, Fakultas Kehutanan, Institut Pertanian Bogor.

Supranto J. 2000. Statistik: Teori dan Aplikasi Jilid 1 Ed ke-6. Jakarta: Erlangga.

Swets JA. 1988. Measuring the Accuracy of Diagnostic Systems. [terhubung berkala]. http://www.jstor.org/stable/1701052?seq=1\&cid=pdf-refence\#references_tab_contents [30 September 2016].

Qoriani HF. 2012. Sistem informasi geografis untuk mengetahui tingkat pencemaran limbah pabrik di Kabupaten Sidoarjo. Jurnal Lingkungan. 17(2): 1-8.

Walls SC, Barichivich WJ., Brown ME. 2013. Drought, deluge, and declines: the impact of precipitation extremes on amphibians in changing climate. Biology. 2: 399-418.

Zawacki CLR. 2009. Effects of slope and riparian habitat connectivity on gene flow in an endangered panamanian frog Atelopus varius. Diversity and Distributions. 15: 796-806. 